\title{
Putrescine Content Parallels Ammonia and Arginine Metabolism in Developing Flowers of the 'Washington' Navel Orange
}

\author{
Oded Sagee ${ }^{1}$ and Carol J. Lovatt \\ Department of Botany and Plant Sciences, University of California, Riverside, CA 92521
}

Additional index words. Citrus sinensis, polyamides, spermidine, spermine, tyrosine

\begin{abstract}
Maximum leaf $\mathrm{NH}_{3}-\mathrm{NH}_{4}^{+}$content and activity of the de novo arginine biosynthetic pathway occurred during the 1st week after transfer of 5-year-old rooted cuttings of the 'Washington' navel orange (Citrus sinensis $\mathbf{L}$. Osbeck) from 8 weeks of low-temperature stress [8-hour days $\left(500 \mu \mathrm{mol} \cdot \mathrm{s}^{-1} \cdot \mathrm{m}^{-2}\right)$ at 15 to $18 \mathrm{C} / 16$-hour nights at 10 to $13 \mathrm{C}$ ]. Both aspects declined in parallel during the subsequent 4 weeks of 12 -hour days $\left(500 \mu \mathrm{mol}^{-1} \cdot \mathrm{s}^{-2}\right)$ at $24 \mathrm{C} / 12$-hour nights at 19C, which culminated in maximum bloom. Apical flowers of inflorescences initiated in response to 8 weeks of low-temperature stress exhibited maximum tissue concentrations of $\mathrm{NH}_{3}-\mathrm{NH}_{4}^{+}$and putrescine, and maximum activity of the de novo arginine biosynthetic pathway 1 week after transfer of the trees from the low-temperature induction to the higher temperature (flower buds were $7 \times 5 \mathrm{~mm}$, length/width). All three criteria decreased in parallel as flowers developed through Stage V (petal fall). In contrast, spermine concentration increased 7-fold during Stage IV of flower development (flower opening). By Stage $\mathrm{V}$, ovaries contained about equal concentrations of putrescine, spermidine, and spermine. The activity of the de novo tyrosine biosynthetic pathway exhibited a pattern of change independent of flower $\mathrm{NH}_{3}-\mathrm{NH}_{4}^{+}$concentration. Observed changes were not due to increased organ weight or size and persisted when the data were expressed per milligram protein. The results of this study demonstrate that leaves and floral buds undergo parallel changes in $\mathbf{N}$ metabolism in response to low-temperature, stress-induced flowering and provide evidence that flower $\mathrm{NH}_{3}-\mathrm{NH}_{4}^{+}$content and putrescine synthesis via argine are metabolically correlated during flower development in $C$. sinensis.
\end{abstract}

Flower formation in Citrus species is promoted by drought or low temperature, followed by restoration of climatic conditions favorable for growth. (Lovatt et al., 1988a; Monselise, 1985; Monselise and Goren, 1969; Monselise and Halevy, 1964; Southwick and Davenport, 1986). Lovatt et al. (1988a, 1988b) have quantified changes in leaf concentrations of several carbon and $\mathrm{N}$ compounds that occur during the low-temperature or waterdeficit stress induction period and during the 4 weeks after removal of the stress, which culminates in full bloom. For both 5 -year-old rooted cuttings of the 'Washington' navel orange induced to flower by low-temperature stress and 16-year-old commercially producing 'Frost Lisbon' lemon trees induced to flower by water-deficit stress, the increase in leaf $\mathrm{NH}_{3}-\mathrm{NH}_{4}{ }^{+}$ content paralleled the duration and severity of the stress. Flower number was significantly correlated with leaf $\mathrm{NH}_{3}-\mathrm{NH}_{4}{ }_{4}^{+}$content: $P<0.0001$ for low-temperature-induced flowering in the 'Washington' navel orange and $P<0.05$ for water-deficit stress-induced flowering in the field-grown 'Frost Lisbon' lemon. No changes occurred in leaf concentration of total $\mathrm{N}$, nitrate, glucose, or starch either during or after the induction treatments:

A cause and effect relationship between tree $\mathrm{NH}_{3}-\mathrm{NH}_{4}^{+}$status and floral intensity was established by subjecting trees to minimal stress and artificially raising the $\mathrm{NH}_{3}-\mathrm{NH}_{4}^{+}$content of the

Received for publication 14 Feb. 1990. We thank Anne Cheng for her capable assistance. This research was supported in part by grants from BARD-The United States Binational Agricultural Research and Development Fund, no. I86784 to C.J.L. and SI-050-86 to C.J.L. and O.S., by a grant from the Citrus Research Board to C.J.L., and by the Citrus Research Center and Agricultural Experiment Station of the Univ. of California, Riverside. Use of a company or product name does not imply approval or recommendation of the product to the exclusion of others that also may be suitable. The cost of publishing this paper was defrayed in part by the payment of page charges. Under postal regulations, this paper therefore must be hereby marked advertisement solely to indicate this fact.

${ }^{1}$ BARD Post-Doctoral Fellow while at the Univ. of California, Riverside. Present address: Dept. of Citriculture, Volcani Center, Bet-Dagan, Israel. tree by foliar application of low-biuret urea at the end of the minimal stress treatments. Increasing the leaf $\mathrm{NH}_{3}-\mathrm{NH}_{4}^{+}$content by foliar application of urea significantly increased the number of floral shoots and the number of flowers per shoot but did not influence the number of vegetative shoots produced (Lovatt et al., 1988b).

Taken together these results suggest that $\mathrm{NH}_{3}-\mathrm{NH}_{4}^{+}$, or its metabolize, may be a factor regulating flower development in Citrus species. Of additional interest to us was the question of whether arginine might play a role in flower development in Citrus. Previous work by Rabe and Lovatt (1986a, 1986b) demonstrated that for several species and hybrids of Citrus, the activity of the pathway for the de novo biosynthesis of arginine was accelerated in response to increased leaf levels of endogenously generated $\mathrm{NH}_{3}-\mathrm{NH}_{4}{ }^{+}$or exogenously supplied $\mathrm{NH}_{4}{ }^{+}$. Since flower formation in citrus is promoted by stress, it is interesting to note that arginine, not ornithine, serves as the precursor of putrescine biosynthesis during stress (Flores and Galston, 1984a, 1984b; Galston, 1983). Arginine or putrescine supplied exogenously increased flower formation in apple (Edwards, 1986). These and the following observations strongly suggest that the synthesis and tissue content of polyamides might also be elevated during early flower development. In the culture of thin layers of tobacco epidermis, adventitious flowering was promoted by spermidine and inhibition of spermidine synthesis prevented flowering (Kaur-Sawhney et al., 1988). With intact tobacco plants, hydroxycinnamoyl putrescine was demonstrated to influence flowering (Martin-Tanguy, 1985) and polyamine mutants exhibited abnormal flower organogenesis (Malmberg, 1980; Malmberg and McIndoo, 1983). Early flower, especially ovary, development is characterized by cell division. Increased polyamine biosynthesis in rapidly dividing cells has been reported in plant tissues (Speranza and Bagni, 1977). Ovary growth in tomato was reduced by inhibition of polyamine synthesis by $\alpha-$ difluoromethylornithine; supplying putrescine in the presence of the inhibitor restored normal ovary development (Cohen et al., 1982). 
The current study was undertaken to determine if flower induction by low-temperature stress would result in elevated levels of $\mathrm{NH}_{3}-\mathrm{NH}_{4}^{+}$in developing Citrus flowers and to define the relationship between the pool size of available $\mathrm{NH}_{3}-\mathrm{NH}_{4}^{+}$, the activity of the pathway for the de novo biosynthesis of arginine, and tissue concentrations of the polyamides putrescine (Put), spermidine (Spd) and spermine (Spin) during development of stress-induced flowers of the 'Washington' navel orange.

To determine whether $\mathrm{NH}_{3}-\mathrm{NH}_{4}^{+}$availability influences amino acid biosynthesis in general or only the synthesis of some amino acids, we also assessed the activity of the pathway for the de novo biosynthesis of tyrosine during development of the 'Washington' navel orange flower. Thus, we also report a new method for assessing the capacity of intact cells to synthesize tyrosine de novo via the shikimic acid pathway.

\section{Materials and Methods}

Chemicals. All radiolabeled chemicals were purchased from ICN Pharmaceuticals (Irvine, Calif.) Liquiscint (liquid scintillation cocktail) was purchased from National Diagnostics (Somerville, N.J.). Mineral salts for Hoagland's and Shive's nutrient solutions were of analytical reagent quality from Fisher Scientific (Pittsburgh). All other chemicals were purchased from Sigma (St. Louis).

Plant material. Five-year-old rooted cuttings of the 'Washington' navel orange grown in pots containing $\approx 19$ liter of Univ. of California soil mix were induced to flower by subjecting the trees to low temperature, $8-\mathrm{hr}$ days $\left(500 \mu \mathrm{mol} \cdot \mathrm{s}^{-1} \cdot \mathrm{m}^{-2}\right.$, at 15 to $18 \mathrm{C} / 16-\mathrm{hr}$ nights at 10 to $13 \mathrm{C}$ for 8 weeks, and then transferring the trees to $12-\mathrm{hr}$ days $\left(500 \mu \mathrm{mol} \cdot \mathrm{s}^{-1} \cdot \mathrm{m}^{-2}\right)$ at $24 \mathrm{C} / 12$ hr nights at 19C (Moss, 1969). Trees were watered once a week with half-strength Hoagland's nutrient solution and as needed with $\mathrm{H}_{2} \mathrm{O}$. Flowers at various stages of development borne at the apex of inflorescences were harvested weekly according to the criteria of Goldschmidt et al. (1980) and Harris and Dugger (1986) (Fig. 1A). In addition, to reduce biological variation, a size criterion was also employed in selecting flowers at each developmental stage (Fig. 1B).

Developing flowers were collected from Stage I $(7 \times 5 \mathrm{~mm}$, length/width) through Stage V, petal fall (Fig. $1 \mathrm{~A}$ and B). At each harvest, fresh weight and protein content (Bradford, 1976) were determined for the flowers used in the assays described below.

Flower $\mathrm{NH}_{3}-\mathrm{NH}_{4}^{+}$and polyamine content. Excised flowers (1 $\mathrm{g}$ fresh weight) were immediately homogenized in $5 \mathrm{ml} 10 \%$ trichloroacetic acid (TCA) using a Polytron tissue homogenizer (PCU-2, Brinkman Instruments) at speed 6. The probe was rinsed with $5 \mathrm{ml} \mathrm{10 \%} \mathrm{TCA,} \mathrm{which} \mathrm{was} \mathrm{added} \mathrm{to} \mathrm{the} \mathrm{homogenate.} \mathrm{The}$ homogenate was centrifuged at $10,000 \times g$ at $4 \mathrm{C}$ for $10 \mathrm{~min}$. The $\mathrm{NH}_{4}^{+}$content of the acid soluble supernatant fraction, containing the combined pool of $\mathrm{NH}_{3}-\mathrm{NH}_{4}^{+}$as $\mathrm{NH}_{4}^{+}$, was determined using a Wescan Ammonia Analyzer (Carlson, 1978). The assay was linear for $\mathrm{NH}_{4}^{+}$concentrations from 0 to $100 \mu \mathrm{g} \cdot \mathrm{ml}^{-1}$. Samples were diluted to give values in this range.

The free polyamine content of the supernatant fraction was determined after benzoylation by reverse phase high performance liquid chromatography at room temperature through a 4.6 $\times 250 \mathrm{~mm}, 5-\mu \mathrm{m}$ particle size C18 column (octadecylsilane; Alltech, Deerfield, Ill.) eluted with $60 \%$ methanol at a flow rate of $1 \mathrm{ml} \cdot \mathrm{min}^{-1}$ (Flores and Galston, 1982). The benzoylpolyamines were detected at $254 \mathrm{~nm}$ at a sensitivity of 0.04 absorbance units full scale. The assay was linear for concentrations of putrescine, spermidine, and spermine from 0.01 to 1 nmol. Ben-

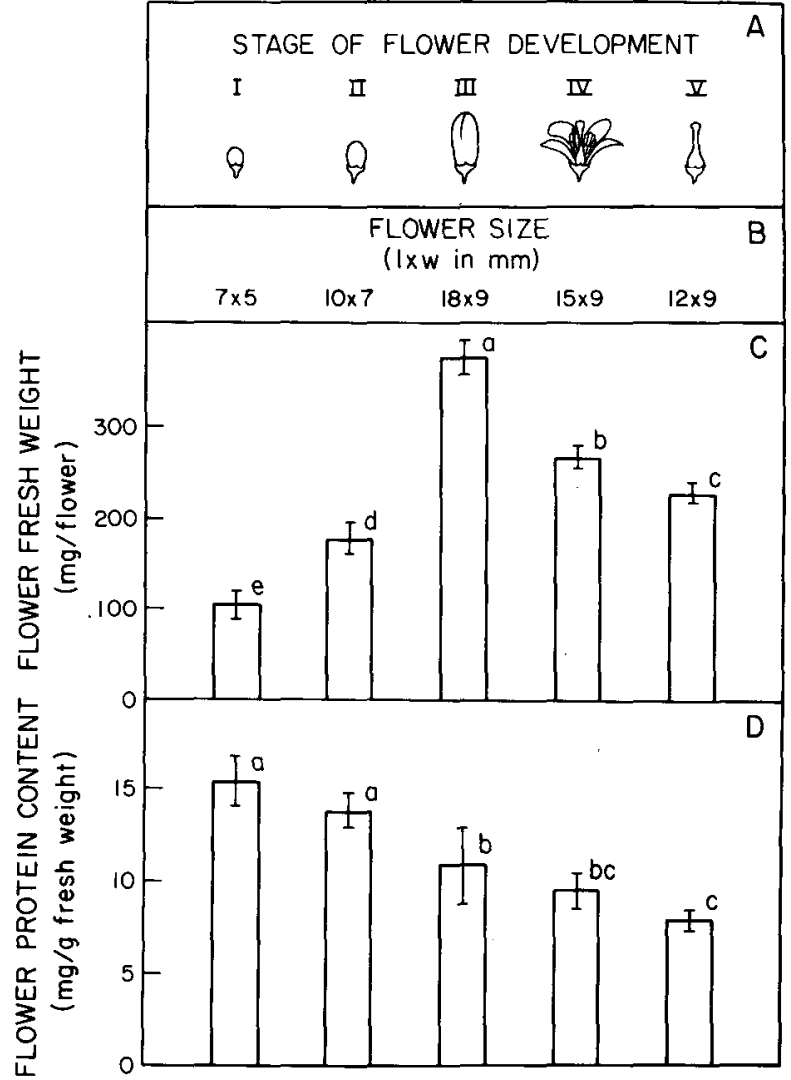

Fig. 1. Stages of 'Washington' navel orange flower development (A) and changes in size (B), fresh weight (C), and protein content (D) during development of 'Washington' navel orange flower. Data are the mean $\pm S D$ for four replicates (10 to 50 flowers in each) from two separate experiments inducing flowering by low-temperature stress. Mean separation was by Duncan's multiple range test at $P<$ 0.05 .

zoylation permitted recovery of $76 \% \pm 11 \%$ of known amounts of putrescine, spermidine, or spermine added to the citrus flower extracts.

Incorporation of $\mathrm{NaH}^{14} \mathrm{CO}_{3}$ into the combined pool of arginine plus urea. Activity of the de novo arginine biosynthetic pathway was assessed in the intact cells of developing flowers (500 mg of fresh weight tissue from flowers cut in half longitudinally and then in half transversely) by measuring the incorporation of radiolabeled carbon supplied as $\mathrm{NaH}^{14} \mathrm{CO}_{3}[5 \mathrm{~mm}$, $37.5 \mu \mathrm{Ci}(1 \mathrm{Ci}=37 \mathrm{GBq})$ ] into the combined pool of arginine plus urea during a 3-hr incubation period in Shive's nutrient solution. The amounts of [guanido- ${ }^{14} \mathrm{C}$ ]arginine and $\left[{ }^{14} \mathrm{C}\right]$ urea synthesized from $\mathrm{NaH}^{14} \mathrm{CO}_{3}$ by the flowers were determined using commercial arginase and urease, as described by Lovatt and Cheng (1984).

Incorporation of $\left[{ }^{14} \mathrm{C}\right]$ glucose into tyrosine. Samples of $1 \mathrm{~g}$ fresh weight of flowers (cut in half longitudinally and then in half transversely) were routinely preincubated in $10 \mathrm{ml}$ of Shive's nutrient solution (Lovatt, 1983), $\mathrm{pH} \mathrm{7.6,} \mathrm{for} 2 \mathrm{hr}$ at 37C in a water bath-shaker. At the end of the preincubation period, the nutrient solution was decanted, and the tissue was immediately transferred to fresh Shive's nutrient solution supplemented with $\left[\mathrm{U}-{ }^{14} \mathrm{C}\right]-\beta-\mathrm{D}$-glucose $(2 \mathrm{mM}, 5 \mu \mathrm{Ci})$ in a final volume of $10 \mathrm{ml}$, $\mathrm{pH}$ 7.6. Reactions were incubated for $4 \mathrm{hr}$ at $37 \mathrm{C}$ in a water bath-shaker. Incorporations were carried out in a 50-ml Erlenmyer flask sealed with a rubber stopper, fitted with a plastic center well (Kontes Glassware, Vineland, N.J.) containing a 
filter paper wick. At the end of the incorporation period, 0.3 $\mathrm{ml}$ of $4 \mathrm{~N} \mathrm{KOH}$ was injected into the plastic center well and the reaction was terminated by injecting $1 \mathrm{ml}$ of $6 \mathrm{~N} \mathrm{HClO}_{4}$ into the main chamber of the flask. The flasks were returned to the water bath-shaker for an additional $10 \mathrm{~min}$ to allow any ${ }^{14} \mathrm{CO}_{2}$ generated during the incubation to distill from the acidified incubation mixture into the $\mathrm{KOH}$ in the center well. The contents of the main chamber of the flask were homogenized with a Polytron tissue homogenizer at speed 6. The Polytron probe was

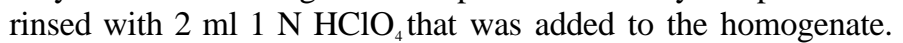
The insoluble material was removed by centrifugation at $10,000 \times$ $g$ for $10 \mathrm{~min}$ at $4 \mathrm{C}$. The acid-soluble supernatant fraction was neutralized with $4 \mathrm{~N} \mathrm{KOH}$ and the resulting precipitate of $\mathrm{KClO}_{4}$ was removed by centrifugation. The neutralized acid-soluble supernatant fraction was diluted to $60 \mathrm{ml}$ with distilled $\mathrm{H}_{2} \mathrm{O}$ and saturated at the boiling point with $300 \mathrm{mg}$ L-tyrosine. The tyrosine synthesized from radiolabeled glucose during incubation was isolated from the neutralized acid-soluble fraction by cocrystallization with the carrier L-tyrosine as the solution cooled slowly to room temperature and then to $4 \mathrm{C}$ overnight in a refrigerator. Crystals were collected by suction filtration, washed with cold distilled $\mathrm{H}_{2} \mathrm{O}$, and recrystallized to a constant specific radioactivity. Aliquots of $40 \mathrm{mg}$ of crystals dried to a constant weight at $70 \mathrm{C}$ were dissolved in $4 \mathrm{ml} 0.5 \mathrm{~N} \mathrm{KOH}$ to determine the content of radioisotope.

Identity of the metabolite of $\left[{ }^{14} \mathrm{C}\right]$ glucose that co-crystallized with carrier tyrosine. The identity of the metabolize of $\left[{ }^{14} \mathrm{C}\right]$ glucose that co-crystallized with carrier tyrosine was determined by thin layer chromatography (TLC) on Silica gel G plates employing (i) $96 \%$ ethanol : water [70:30 (v/v)], (ii) 80 N-butanol :20 acetic acid :20 water (by volume), and (iii) $96 \%$ ethanol : $34 \% \mathrm{NH}_{4} \mathrm{OH}[70: 30,(\mathrm{v} / \mathrm{v})]$ as the developing solvents. Marker L-tyrosine, run in parallel with the sample, was located with a UV light and the corresponding area from the chromatogram of the sample was cut out and eluted in $4 \mathrm{ml}$ of $0.5 \mathrm{~N}$ $\mathrm{KOH}$ to determine its content of radioisotope.

Determination of radioisotope content. Samples to determine the content of radioisotope were prepared as described above. In all cases, the samples were subsequently diluted with $13 \mathrm{ml}$ of Liquiscint and the content of radioisotope measured using a Beckman LS100 liquid scintillation spectrometer (Beckman Instruments, Irvine, Calif.). Quenching was determined by an automatic external standardization system of quench analysis. A standard quench curve was determined by using a series of samples containing a known quantity of ${ }^{14} \mathrm{C}$ radioactivity and increasing amounts of chemical quencher.

Presentation of data. Data are the mean \pm SD for at least two sampling dates for each stage of flower development from each of two separate experiments that induced flowering by lowtemperature stress $(n=4)$. Separation of the means was by Duncan's multiple range test, at $P=0.05$.

\section{Results}

Consistent with the accumulation of $\mathrm{NH}_{3}-\mathrm{NH}_{4}{ }_{4}$ in developing floral buds during low-temperature stress-induced flowering in the 'Washington' navel orange, the $\mathrm{NH}_{3}-\mathrm{NH}_{4}{ }^{+}$concentration was highest in Stage I flowers $\left(356 \pm 27 \mu \mathrm{g} \cdot \mathrm{g}^{-1}\right.$ fresh weight)( $P$ $<0.05$ ) (Fig. 2A). Stage I flowers were collected 1 week after transfer of the trees from the low-temperature induction treatment to the higher temperature. $\mathrm{NH}_{3}-\mathrm{NH}_{4}{ }^{+}$concentration decreased through all subsequent stages of flower development to a low of $87 \pm 6 \mu \mathrm{g} \cdot \mathrm{g}^{-1}$ fresh weight ovary tissue at petal fall (Fig. 2A) $(P<0.05)$.

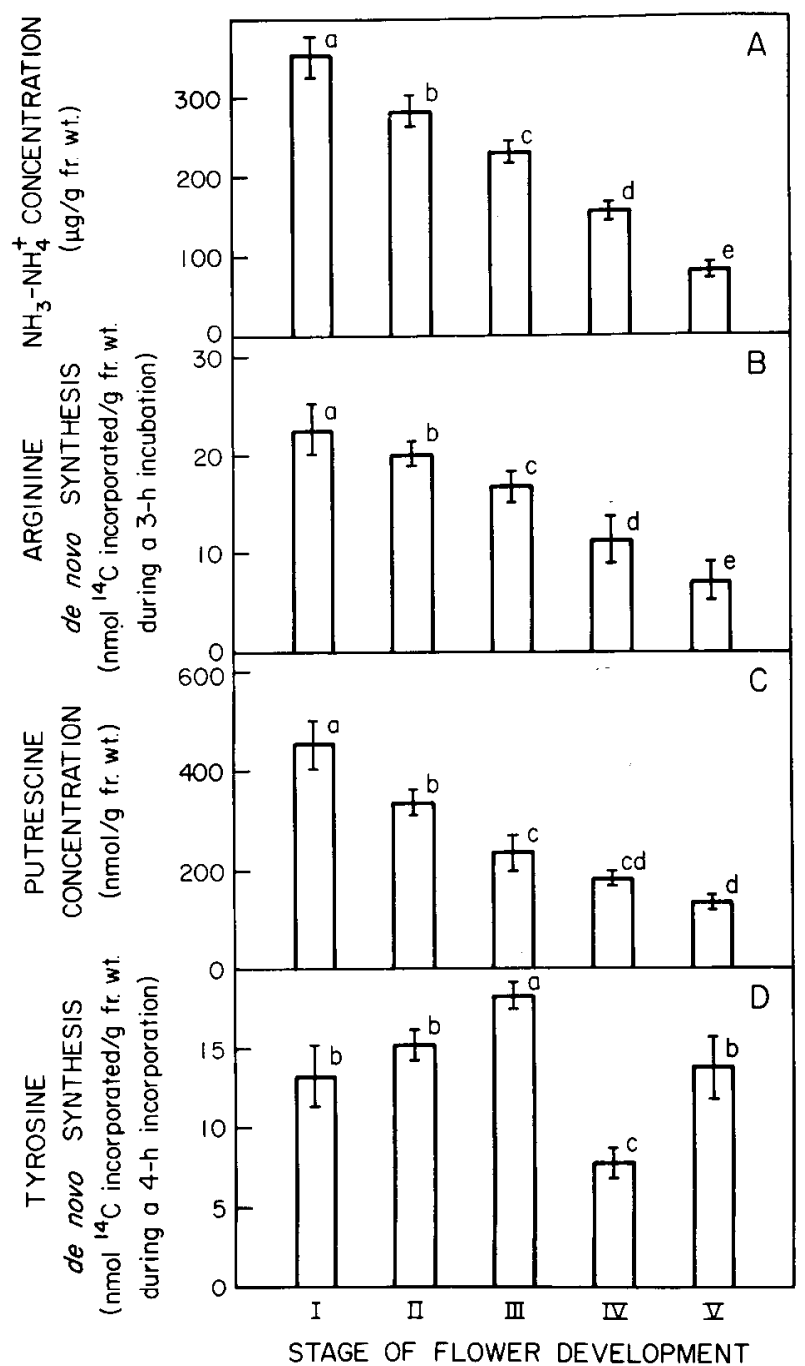

Fig. 2. Changes in $\mathrm{NH}_{3}-\mathrm{NH}_{4}^{+}$concentration (A), activity of the de novo arginine biosynthetic pathway (B), putrescine concentration (C), and activity of the de novo tyrosine biosynthetic pathway (D) in developing flowers of the 'Washington' navel orange. Data are the mean $\pm S D$ of four replicates from two separate experiments inducing flowering by low-temperature stress. Mean separation was by Duncan's multiple range test, $P<0.05$.

Maximum activity of the pathway for the de novo biosynthesis of arginine was observed in Stage I flowers; the activity of this pathway decreased during flower development in a manner similar to the decrease in flower $\mathrm{NH}_{3}-\mathrm{NH}_{4}{ }^{+}$content (Fig. 2B). Putrescine concentration of developing flowers exhibited the same pattern of change (Fig. 2C).

The changes in these characteristics were not inversely related to the increase in organ fresh weight or size. There was a 2 fold increase in organ fresh weight between Stage II and Stage III, a concomitant decrease in $\mathrm{NH}_{3}-\mathrm{NH}_{4}{ }^{+}$concentration, arginine biosynthesis, or putrescine content was not observed (Figs. 1C and 2). Flower weight peaked at Stage III while $\mathrm{NH}_{3}-\mathrm{NH}_{4}^{+}$concentration, activity of the de novo arginine biosynthetic pathway and putrescine content decreased continuously through Stages I to $\mathrm{V}$ of flower development (Figs. 1C and 2).

Protein per gram fresh weight of navel orange flowers decreased gradually during development (Fig. ID). Expressing concentrations of $\mathrm{NH}_{3}-\mathrm{NH}_{4}{ }^{+}$or putrescine or rate of de novo arginine biosynthesis per milligram protein did not alter the 
overall pattern of continued decrease in these quantities from Stages I to V.

The decrease in available $\mathrm{NH}_{3}-\mathrm{NH}_{4}^{+}$and concomitant decrease in the activity of the pathway for the de novo biosynthesis of arginine observed in developing flowers also occurred in leaves during the 4 weeks following, removal of the stress (Fig. 3).

Total polyamine content $(\Sigma$ Put + Spd + Spin $)$ of developing flowers was inversely related to the increase in flower fresh weight for Stages I through IV (Table 1). While putrescine was always the greatest fraction, with the exception of Stage IV of

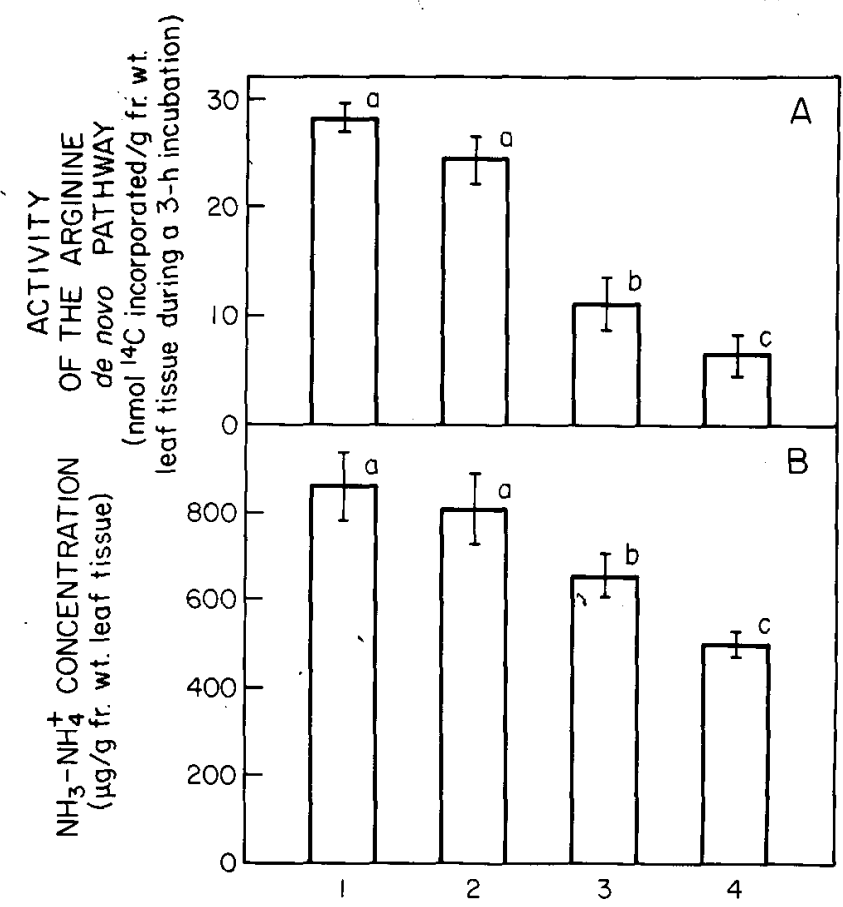

WEEKS AT 24C/I9C (DAY/NIGHT) FOLLOWING 8 WEEKS OF LOW-TEMPERATURE STRESS

Fig. 3. Changes in $\mathrm{NH}_{3}-\mathrm{NH}_{4}^{+}$concentration (A) and activity of the de novo arginine biosynthetic pathway $(\mathbf{B})$ in young fully expanded leaves from 'Washington' navel orange trees subjected to 8 weeks of low-temperature stress [ 8 -hr days $\left(500 \mu \mathrm{mol} \cdot \mathrm{s}^{-1} \cdot \mathrm{m}^{-2}\right)$ at 15 to $18 \mathrm{C} / 16$-hr nights at 10 to $13 \mathrm{C}$. Measurements were made weekly beginning 1 week after trees were transferred from the low-temperature treatment to $24 / 19 \mathrm{C}$ (day/night). Data are the mean $\pm \mathrm{SD}$ for three separate experiments that induced flowering. Mean separation was by Duncan's multiple range test, $P<0.05$. flower development, its concentration relative to the concentration of total polyamides decreased through development. Spermidine concentration of developing flowers decreased significantly $(P<0.05)$ from Stage I to Stage II. However, spermidine concentration was $\approx 30 \% \pm 6 \%$ of the $\Sigma$ Put + Spd + Spm throughout flower development. The concentration of spermine decreased through Stage III and then increased $\approx 7$-fold at Stage IV (flower opening). These shifts in individual polyamides resulted in the concentration of each being about equal in Stage $\mathrm{V}$ of flower development.

Changes in the activity of the shikimic acid pathway for the de novo biosynthesis of tyrosine (Fig. 2D) during flower development were significantly different from those observed for the arginine de novo pathway (Fig. 2B). Tyrosine de novo biosynthesis increased significantly as flowers developed from Stage I through Stage III, but dropped sharply in Stage IV. Stage V flowers exhibited a rate of tyrosine biosynthesis equal to those of Stage I and II flowers. Optimal conditions for assessing the activity of the shikimic acid pathway in the intact cells of citrus tissues were $2 \mathrm{~mm}$ glucose (final concentration) and a 2-hr preincubation period followed by a 4-hr incubation, both at 37C (data not shown).

Due to the differences in the optimal conditions for assaying de novo arginine and tyrosine biosynthesis, the capacities of the two pathways cannot be compared. However, since the activities of both pathways were assessed under optimal conditions, the patterns of change in the activities of the two pathways during flower development can be contrasted. The maximum rate of incorporation of $\mathrm{NaH}^{14} \mathrm{CO}_{3}$ into the combined pool of arginine plus urea was observed at Stage I of flower development while the maximum rate of incorporation of $\left[{ }^{14} \mathrm{C}\right]$ glucose into tyrosine occurred at Stage III. In addition, the minimum activities of the arginine and tyrosine biosynthetic pathways occurred at different stages of flower development, Stages V and IV, respectively (Fig. $2 \mathrm{~B}$ and D).

Identity of the metabolize of $\left[{ }^{14} \mathrm{C}\right]$ glucose that co-crystallizes with L-tyrosine. The reliability of the method for the recovery of $\left[{ }^{14} \mathrm{C}\right] \mathrm{L}$-tyrosine by co-crystallization with carrier was verified by TLC in three solvent systems. The radiolabeled metabolize of $\left[{ }^{14} \mathrm{C}\right]$ glucose isolated by co-crystallization with carrier tyrosine co-chromatographed with commercial tyrosine. In addition, virtually all of the radiolabel isolated by co-crystallization with carrier tyrosine and applied to the chromatogram was recovered in the area of the chromatogram co-chromatographing with commercial tyrosine: compare $800 \mathrm{dpm}$ before chromatography to 720,750 , and $710 \mathrm{dpm}$ after chromatography in the three systems listed, respectively, in Materials and Methods.

Table 1. Changes in the polyamine content of developing 'Washington' navel orange flowers.

\begin{tabular}{lccccc}
\hline & \multicolumn{5}{c}{ Stage of flower development } \\
\cline { 2 - 6 } Polyamine & I & II & III & IV & V \\
\hline & & $n m o l \cdot g^{-1}$ fresh $w t(\%$ of $\Sigma P u t+S p d+S p m)$ & \\
SPut + Spd + Spm & $733 \pm 53 \mathrm{a}$ & $533 \pm 33 \mathrm{~b}$ & $396 \pm 71 \mathrm{~cd}$ & $493 \pm 78 \mathrm{bc}$ & $361 \pm 42 \mathrm{~d}$ \\
Putrescine & $466 \pm 64 \mathrm{a}$ & $334 \pm 27 \mathrm{~b}$ & $240 \pm 34 \mathrm{c}$ & $182 \pm 19 \mathrm{~cd}$ & $134 \pm 15 \mathrm{~d}$ \\
& $(63.6 \%)$ & $(62.6 \%)$ & $(60.4 \%)$ & $(36.9 \%)$ & $(37.1 \%)$ \\
Spermidine & $212 \pm 25 \mathrm{a}$ & $163 \pm 6 \mathrm{~b}$ & $126 \pm 26 \mathrm{bc}$ & $106 \pm 14 \mathrm{c}$ & $133 \pm 14 \mathrm{bc}$ \\
& $(29.0 \%)$ & $(30.5 \%)$ & $(31.8 \%)$ & $(21.6 \%)$ & $(36.8 \%)$ \\
Spermine & $54.5 \pm 33.4 \mathrm{~b}$ & $36.5 \pm 5.7 \mathrm{~b}$ & $29.6 \pm 11.8 \mathrm{~b}$ & $204 \pm 66.1 \mathrm{a}$ & $88.3 \pm 41.8 \mathrm{~b}$ \\
& $(7.4 \%)$ & $(6.8 \%)$ & $(7.5 \%)$ & $(41.5 \%)$ & $(24.4 \%)$ \\
\hline
\end{tabular}

${ }^{2}$ Data are the mean $\pm S D$ of two separate experiments inducing flowering by low-temperature stress. In each experiment, there were two sampling dates for each stage of development. Mean separation within rows was by Duncan's multiple range test at $P<0.05$. 


\section{Discussion}

Previous studies on $\mathrm{N}$ content of citrus flowers were concerned with nutritional problems (Cameron and Appleman, 1934) or hesperidin content (Goren and Monselise, 1964). Changes in $\mathrm{NH}_{3}-\mathrm{NH}_{4}^{+}$content and metabolism have not previously been investigated during flower development in citrus. Total $\mathrm{N}$ content of whole flowers decreased through Stage IV of development but exhibited a slight increase at Stage V despite the drop of petals and stamens (Goren and Monselise, 1964). Flower $\mathrm{NH}_{3}-\mathrm{NH}_{4}^{+}$and putrescine content and rate of de novo arginine biosynthesis decreased in parallel through all five stages of flower development.

Due to the difficulties anticipated in conducting an in-depth biochemical study of the changes in polyamine metabolism in citrus buds during flower initiation, this initial study was undertaken to determine if changes in $\mathrm{NH}_{3}-\mathrm{NH}_{4}{ }^{+}$metabolism observed to occur in leaves during the period of flower induction arid the subsequent 4 weeks leading to flower opening were specific to leaf tissue or reflected parallel changes occurring in the developing flower. Thus, no attempts were made to establish differences in $\mathrm{N}$ metabolism in various flower parts.

The observation that flowers in the earliest stage of development (Stage I) had the highest concentration of $\mathrm{NH}_{3}-\mathrm{NH}_{4}^{+}$ suggests that $\mathrm{NH}_{3}-\mathrm{NH}_{4}^{+}$accumulates in floral buds initiated in response to low-temperature stress. Flower $\mathrm{NH}_{3}-\mathrm{NH}_{4}^{+}$content decreased during the 4 weeks at the higher temperature leading to flower opening concurrent with a decrease in leaf $\mathrm{NH}_{3}$ $\mathrm{N} \mathrm{H}_{4}^{+}$content. In addition, for both organs the activity of the pathway for the de novo biosynthesis of arginine decreased in parallel with the decrease in tissue $\mathrm{NH}_{3}-\mathrm{NH}_{4}^{+}$content. The data established that the observed decreases were not dilution effects resulting from increased flower fresh weight or size. Leaf analyses always employed the youngest fully expanded leaves. Thus, at each sampling date, the stage of leaf development was always the same. Our ability to successfully select young, fully expanded leaves of similar physiological age was reported previously (Rabe and Lovatt, 1984). Thus, the decreases in leaf $\mathrm{NH}_{3}$ $\mathrm{NH}_{4}{ }^{+}$content and rate of de novo arginine biosynthesis observed during the 4 weeks following removal of the stress were not a result of continued leaf expansion, maturation, or senescence.

The results of this study clearly establish that leaves and floral buds are undergoing parallel changes in $\mathrm{N}$ metabolism during the process of flower ontogeny leading to flower opening. Whether leaves are essential to the process as the initial source of $\mathrm{NH}_{3}$ $\mathrm{NH}_{4}^{+}$and/or arginine and putrescine remains to be determined.

Taken together, the results of this study provide evidence consistent "with our previous report (Rabe and Lovatt, 1986a) that the activity of the arginine de novo biosynthetic pathway is responsive to changes in tissue levels of $\mathrm{NH}_{3}-\mathrm{NH}_{4}^{+}$and extends this observation from leaves to flowers and fruit of Citrus sinensis. In addition, this study provides evidence that the synthesis of tyrosine is not influenced by tissue $\mathrm{NH}_{3}-\mathrm{NH}_{4}^{+}$concentrations. In light of these results, the fact that de novo arginine biosynthesis and putrescine levels do change in parallel with flower $\mathrm{NH}_{3}-\mathrm{NH}_{4}^{+}$content suggests that they are metabolically linked during development of the navel orange flower.

The synthesis of putrescine from arginine in the navel orange flower is consistent with previous research demonstrating that arginine decarboxylase activity was always higher than ornithine decarboxylase activity (2- to 8-fold) during the development of flowers and ovaries of Citrus reticulata (Nathan et al., 1984). Avocado fruit mesocarp and seed coat exhibited arginine decarboxylase during all stages of fruit growth, development, and ripening; ornithine decarboxylase could not be detected (Apelbaum, 1986).

The continuous decrease in putrescine concentration during flower development was not reflected in a concomitant increase in spermidine and/or spermine concentration. The levels of these two polyamides remained relatively constant throughout flower development, with the exception that the spermine content of the ovary increased 7-fold between Stages III and IV. High polyamine biosynthetic activities and accumulation were previously reported to be associated with the early states of citrus fruit development characterized by cell division (Nathan et al., 1984). Whether the increased availability of spermine is essential to fruit set and development in citrus is unknown. Exogenous application of putrescine $\left(10^{-4} \mathrm{M}\right)$ to apple flowers increased flower retention, fruit set, and yield per tree. Putrescine increased fruit growth during the cell division phase of apple growth, but not thereafter (Costa et al., 1986).

In a study of flower development in apple (Biasi et al., 1988), flower opening was accompanied by a dramatic increase in all three polyamides. In citrus, only spermine content increased (7fold) during flower opening. However, the levels of all three polyamides were significantly higher in open citrus flowers than in apple: 180 vs. 80,100 vs. 40 , and 200 vs. $25 \mathrm{nmol} \cdot \mathrm{g}^{-1}$ fresh weight for putrescine, spermidine, and spermine for flowers of citrus and apple, respectively. In addition, for both citrus and apple flowers, changes in putrescine content paralleled changes in protein content. A direct relationship between polyamides and flower growth could not be found for either species. In apple, maximum growth occurred almost entirely before the sharp rise in polyamine levels. In our study, which included earlier stages of flower development, the highest level of total polyamides was observed 7 to 10 days before maximum growth.

The results of this study of $\mathrm{N}$ metabolism in developing citrus flowers suggest that $\mathrm{NH}_{3}-\mathrm{NH}_{4}^{+}$accumulating during stress-induced flowering in citrus results in the stimulation of de novo arginine biosynthesis and in the accumulation of putrescine at an early stage of floral organogenesis, followed by rapid metabolism of these compounds during flower development. The results provide sufficient preliminary data to suggest a cause and effect relationship between flower $\mathrm{NH}_{3}-\mathrm{NH}_{4}^{+}$content and putrescine synthesis via arginine to warrant an in-depth study of the possible role of these metabolizes in regulating flower initiation and development in $C$. sinensis.

\section{Literature Cited}

Apelbaum, A. 1986. Polyamine involvement in the development and ripening of avocado. Acta Hort. 179:779-785.

Bradford, M.M. 1976. A rapid and sensitive method for the quantitation of microgram quantities of protein utilizing the principle of protein-dye binding. Anal. Biochem. 72:248-254.

Biasi, R., N. Bagni, and G. Costa. 1988. Endogenous polyamides in apple and their relationship to fruit set and fruit growth. Physiol. Plant. 73:201-205.

Cameron, S.H. and D. Appleman. 1934, Total nitrogen in developing flowers and young fruits of Valencia orange. Proc. Amer. Soc. Hort. Sci. 32:204-207.

Carlson, R.M. 1978. Automated separation and conductimetric determination of ammonia and dissolved carbon dioxide. Anal. Chem. 50:1528

Cohen, E., S. (Malis) Arad, Y.M. Heimer, and Y. Mizrahi. 1982. Participation of ornithine decarboxylase in early states of tomato fruit development. Plant. Physiol. 70:540-543.

Costa, G., R. Biasi, and N. Bagni. 1986. Effect of putrescine on fruiting performance of apple (cv. Hi Early). Acta Hort. 179:355361. 
Edwards, G.R. 1986. Ammonia, arginine, polyamides and flower initiation in apple. Acta Hort. 1:363.

Flores, H.E. and A.W. Galston. 1982. Analysis of polyamides in higher plants by high performance liquid chromatography. Plant Physiol. 69:701-706.

Flores, H.E. and A.W. Galston. 1984a. Osmotic stress induced polyamine accumulation in cereal leaves. I. Physiological parameters of the response. Plant Physiol. 75:102-109.

Flores, H.E, and A.W. Galston. 1984b. Osmotic stress-induced polyamine accumulation in cereal leaves. II. Relation to amino acid pools. Plant Physiol. 75:110-113.

Galston, A.W. 1983. Polyamides as modulators of plant development. Bioscience 33:382-388.

Goldschmidt, E.E. 1980. Abscisic acid in citrus flower organs as related to floral development and function. Plant Cell Physiol. 21:193195.

Goren, R. and S.P. Monselise. 1964. Survey of hesperidin and nitrogen in the developing flower of the Shamouti orange tree. J. Amer. Soc. Hort. Sci. 85:218-223.

Harris, M.J. and W.M. Dugger. 1986. Levels of free and conjugated abscisic acid in developing floral organs of navel orange (Citrus sinensis [L.] Osbeck cv. Washington). Plant Physiol. 82:11641166.

Kaur-Sawhney, R., A.F. Tiburcio, and A.W. Galston. 1988. Spermidine and flower-bud differentiation in thin-layer explants of tobacco. Planta 173:282-284.

Lovatt, C.J. 1983. De novo purine biosynthesis in intact cells of $\mathrm{Cu}$ curbita pepo. Plant Physiol. 73:766-772.

Lovatt, C.J. and A.H. Cheng. 1984. Aspartate carbamyltransferase: Site of end-product inhibition of the orotate pathway in intact cells of Cucurbita pepo. Plant Physiol. 75:511-515.

Lovatt, C.J., Y. Zheng, and K.D, Hake. 1988a. Demonstration of a change in nitrogen metabolism influencing flower initiation in Citrus. Israel. J. Bot. 37:181-188.

Lovatt, C.J., Y. Zheng, K.D. Hake. 1988b. A new look at the KrausKraybill hypothesis and flowering in Citrus. Proc. 6th Intl. Citrus Congr. 1:475-483.

Malmberg, R.L. 1980. Biochemical, cellular and developmental char- acterization of a temperature-sensitive mutant of Nicotiana tabacum. Cell 22:603-609.

Malmberg, R.L. and J. McIndoo. 1983. Abnormal floral development of a tobacco mutant with elevated polyamine levels. Nature (London) 305:623-625.

Martin-Tanguy, J. 1985. The occurrence and possible function of hydroxycinnamol acid amides in plants. Plant Growth Reg. 3:381-399.

Monselise, S.P. 1985. Citrus and related genera, p. 257-294. In: A.H. Halevy (ed). CRC handbook of flowering, vol. 2. CRC Press, Boca Raton, Fla.

Monselise, S.P. and R. Goren. 1969. Flowering and fruiting-interactions of exogenous and internal factors. Proc. 1st Intl. Citrus Symp. 3:1105-1112.

Monselise, S.P. and A.H. Halevy. 1964. Chemical inhibition and promotion of citrus flower bud induction. Proc. Amer. Soc. Hort. Sci. 84:141-146.

Moss, G.I. 1969. Influence of temperature and photoperiod on flower induction and inflorescence development in sweet orange. J. Hort. Sci. 44:311-320.

Nathan, R., A. Altman, and S.P. Monselise. 1984. Changes in activity of polyamine biosynthetic enzymes and in polyamine contents in developing fruit tissues of 'Murcott' mandarin. Scientia Hort. 22:359364.

Rabe, E. and C.J. Lovatt. 1984. De novo arginine biosynthesis in leaves of phosphorus-deficient Citrus and Ponsirus species. Plant Physiol. 76:747-752.

Rabe, E. and C.J. Lovatt. 1986a. Increased arginine biosynthesis during phosphorus deficiency: A response to the increased ammonia content of leaves. Plant Physiol. 81:774-779.

Rabe, E. and C.J. Lovatt. 1986b. Relative phosphorus dependency of citrus rootstock is reflected in leaf nitrogen metabolism. J. Amer. Soc. Hort. Sci. 111:922-926.

Southwick, S.M. and T.L. Davenport. 1986. Characterization of water stress and low temperature effects on flower induction in citrus. Plant Physiol. 81:26-29.

Speranza, A. and N. Bagni. 1977. Putrescine biosynthesis in Agrobacterium tumefaciens and in normal and crown gall tissues of Scorzonera hispanica L. Z. Pflanzenphysiol. 81:226-233. 